Cakrawala Dini: Jurnal Pendidikan Anak Usia Dini | p-ISSN 2087-I317 | e-ISSN 2621-8321

Vol. 9. No.2 November 2018 | Hal 88-97

\title{
PENINGKATAN KARAKTER TANGGUNG JAWAB MELALUI METODE PROYEK PADA ANAK
}

\author{
Mega Seftyana ${ }^{1}$, Syafdaningsih, Rukiyah \\ Program Studi Pendidikan Guru Pendidikan Anak Usia Dini, FKIP \\ Universitas Sriwijaya
}

\begin{abstract}
This type of research is a classroom action research entitled Character building Responsibility through Project Methods In Child Group B TK Marfu'ah Palembang, aims to improve the character of responsibility through the project method. The subjects of this study were children aged (5-6) years of 16 children consisting of 8 boys and 8 girls in this the academic year 2016-2017. Data collection techniques use observation and test sheets. The result of data analysis indicate that there is an increase of responsibility character from Cycle I, Cycle II, Cycle III, Cycle IV as follows: in Cycle I there are 5 children (31\%) who get minimum score with criteria developed according to expectation (BSH). In Cycle II there were 9 children (56\%) who got the minimum score with the criteria developed according to expectations (BSH). In Cycle III, there were 11 children (69\%) who got the minimum score with the got the minimum developed according to expectations (BSH). And in Cycle IV there are children (82\%) who get the minimum score with the criteria developing as expectations (BSH). Based on the criteria that have been set that is at least $75 \%$ of children in the class get the minimum value to grow as expected. For that in Cycle $I V$ the study was stopped. This can be proved by the dominant indicator arising from Cycle I to Cycle IV that often arises is the child doing the task and completing the task, while the indicator that has not appeared in every cycle is to accept the consequenses and indicators that appear less ineach cycle is to get the results the maximum. For that it is necessary to suggest for further researcher to do research of class action to improve character of responsibility in indicator to get maximum result.
\end{abstract}

Keyword: character of responsibility, Project Method, Kindergarten

\begin{abstract}
Abstrak: Penelitian tindakan kelas yang berjudul Peningkatan Karakter Tanggung Jawab melalui Metode Proyek pada Anak Kelompok B TK Marfu'ah Palembang, bertujuan untuk meningkatkan karakter tanggung jawab melalui metode proyek. Subjek penelitian ini adalah anak berusia (5-6) tahun yang berjumlah 16 anak terdiri dari 8 anak laki-laki dan 8 anak perempuan pada tahun ajaran 2016-2017. Teknik pengumpulan data menggunakan lembar observasi, dan tes. Hasil analisis data menunjukkan adanya peningkatan karakter tanggung jawab dari Siklus I, Siklus II, Siklus III dan Siklus IV secara berturut-turut sebagai berikut: pada Siklus I terdapat 5 anak (31\%) yang mendapatkan nilai minimal dengan kriteria berkembang sesuai harapan (BSH). Pada siklus II terdapat 9 anak (56\%) yang mendapatkan nilai minimal dengan kriteria berkembang sesuai harapan (BSH). Pada Siklus III terdapat 11 anak (69\%) yang mendapatkan nilai minimal dengan kriteria berkembang sesuai harapan (BSH). Dan pada siklus IV terdapat 13 anak (82\%) yang mendapatkan nilai minimal dengan kriteria berkembang sesuai harapan (BSH). Berdasarkan kriteria yang sudah ditetapkan yaitu minimal $75 \%$ anak dalam kelas mendapatkan nilai minimal berkembang sesuai harapan. Untuk itu pada siklus IV penelitian di hentikan. Hal ini dapat dibuktikan dengan indikator yang dominan muncul dari siklus I sampai siklus IV yang sering muncul adalah anak mengerjakan tugas dan menyelesaikan tugas, sedangkan indikator yang belum banyak muncul adalah menerima konsekuensi, dan indikator yang kurang muncul pada setiap siklus adalah mendapatkan hasil yang maksimal. Untuk itu perlu di sarankan bagi peneliti selanjutnya untuk melakukan penelitian tindakan
\end{abstract}

IPGPAUD FKIP Universitas Sriwijaya, Email: mseftyana@yahoo.com

88 Cakrawala Dini: Vol. 9 №. 2, November 2018 
kelas guna meningkatkan karakter tanggung jawab dalam indikator mendapatkan hasil yang maksimal.

Kata Kunci: Karakter Tangggung Jawab, Metode Proyek, TK

\section{PENDAHULUAN}

Pendidikan anak usia dini adalah suatu upaya pembinaan yang ditujukan kepada anak sejak lahir sampai enam tahun yang dilakukan melalui pemberian rangsangan yang cukup dalam mengembangkan jasmani dan rohani agar anak memiliki kesiapan dalam memasuki pendidikan lebih lanjut. Perlakuan dan stimulasi yang positif juga akan membentuk karakter anak. Dalam kehidupan sehari-hari anak sering berinteraksi dengan lingkungannya, anak juga kadang menemukan benda yang ingin di eksplorasinya. Dari penemuan yang ada di lingkungannya anak memiliki rasa ingin tahu yang besar, namun anak sulit memecahkan rasa keingintahuannya. Ada anak yang mendapatkan perlakuan dan stimulan yang positif, sehingga anak tumbuh lebih matang. Namun ada pula anak yang tidak mendapatkan lingkungan yang positif, sehingga perkembangan terlambat. Kondisi yang berbeda-beda tersebut menuntut guru untuk bertindak secara bijak, sesuai dengan kondisi, kemampuan dan kepribadian anak. (Najib, 2016)

Perlakuan dan stimulasi yang positif juga akan membentuk karakter anak. Nilai-nilai karakter anak seperti nilai taat kepada Allah, syukur, ikhlas, sabar, tawakal, percaya diri, rasional, kritis, kreatif, inovatif, mandiri, bertanggung jawab, hidup sehat, pemberani, dapat dipercaya, jujur, rendah hati, tekun, disiplin, teliti, ramah, taat peraturan, empati, menyayangi tanaman, menyayangi hewan, pemurah dan menghormati orang lain. Selain itu lingkungan ditempat tinggal anak mempengaruhi karakter anak. Sebagai contoh karakter yang paling dekat dengan anak adalah karakter tanggung jawab. Anak sangat dituntut untuk bertanggung jawab, misalnya saja membereskan mainan, merapikan alat tulis, berani mengakui kesalahannya. Tanggung jawab kadang dikaitkan dengan keharusan untuk berbuat sesuatu, atau kadang-kadang dihubungkan dengan kesediaan untuk menerima konsekuensi dari suatu perbuatan. Tanggung jawab harus disiapkan sejak anak masih kecil, melalui kegiatan rutin sehari-hari. Anak tidak hanya diminta untuk berprestasi di bidang akademis saja, tetapi juga harus mampu mengurus dirinya sendiri. Dalam memberikan tanggung jawab hendaknya harus peka terhadap kemampuan anak untuk bertanggung jawab. Kemampuan itu tergantung pada usia, kematangan dan kepribadian anak. Dengan belajar bertanggung jawab, maka anak bisa menunjukkan dirinya mampu dan

mengontrol diri sendiri. Sikap tanggung jawab pun akan tumbuh jika anak berhasil mengerjakan sesuatu tugasnya. Anak juga akan belajar bahwa hidup mempunyai konsekuensi terhadap diri, keluarga dan masyarakat. (Yaumi, 2014:74).

Pengalaman belajar sangat penting di berikan untuk memberi stimulasi anak sejak dini. Metode proyek adalah suatu cara pemberian pengalaman belajar dengan menghadapkan anak dengan persoalan sehari-hari yang harus dipecahkan secara berkelompok. (Khayrunnisa, 2014). Metode proyek memberikan kesempatan kepada anak untuk mengembangkan dan melatih anak menerima tanggung jawab dan menggunakan kebebasan secara fisik maupun intelektual dalam penyelesaian pekerjaannya. Dengan metode proyek anak dapat melatih diri untuk mandiri dan percaya diri, menghargai teman, membangun sikap positif terhadap lingkungan dan bekerja bersama, serta 
melatih anak menerima tanggung jawab. Sehingga dengan penggunaan metode proyek dapat menerapkan pengetahuan, sikap dan keterampilan dengan terpadu, anak-anak belajar bersungguh-sungguh dalam bekerja bersama serta bertanggung jawab penuh pada pekerjaannya. Senada dengan penelitian yang di lakukan oleh Siti Arbiah, Indonesian Journal of Early Childhood Education Studies edisi 2014 yang berjudul Penerapan Metode Proyek Untuk Meningkatkan Sikap Tanggung Jawab Pada Anak Kelompok A TKIT Nur Hidayah Surakarta. Hasil penelitian menunjukkan bahwa adanya perkembangan tanggung jawab anak dari siklus 1 pertemuan pertama sebanyak 61 $\%$ dan pada pertemuan ke dua sebanyak $69 \%$ dan pada siklus ke dua pada pertemuan pertama sebanyak $78 \%$ serta pada pertemuan ke dua sebanyak $81 \%$. Sehingga ini menunjukkan peningkatan yang signifikan dan dapat dikatakan bahwa metode proyek efektif untuk meningkatkan karakter tanggung jawab.

Dari hasil pengamatan di atas peneliti tertarik untuk melakukan penelitian tindakan kelas dengan judul "Peningkatan Karakter Tanggung Jawab Melalui Metode Proyek Pada Anak Kelompok B TK Marfu'ah Palembang”. Dan didapatkan rumusan masalah "Apakah Metode Proyek Dapat Meningkatkan Karakter Tanggung Jawab Pada Anak Kelompok B TK Marfu'ah Palembang?" serta tujuan penelitian tindakan kelas ini adalah untuk melihat Peningkatan Karakter Tanggung Jawab Melalui Metode Proyek Pada Anak Kelompok B TK Marfu'ah Palembang.

\section{METODOLOGI PENELITIAN}

Jenis penelitian yang digunakan pada penelitian ini adalah penelitian tindakan kelas (classroom action research). Penelitian tindakan kelas adalah pengkajian masalah pembelajaran di dalam kelas melalui refleksi diri dalam upaya untuk memecahkan masalah tersebut dengan cara melakukan berbagai tindakan yang terencana dalam situasi nyata serta menganalisis setiap pengaruh dari perlakuan tersebut (Wina Sanjaya, 2013, hal 26). Penelitian tindakan kelas adalah penelitian tindakan yang bertujuan untuk memperbaiki mutu praktik pembelajaran di kelas (Suhardjono diikutip Dimyati, 2013). Senada dengan pendapat di atas, Supardi (2013, hal 129) mengatakan bahwa penelitian tindakan kelas adalah bentuk penelitian yang bersifat reflektif, partisipasif, kolaboratif, dan spiral, yang memiliki tujuan untuk melakukan perbaikan sistem, metode kerja, proses, isi, kompetensi, dan meningkatkan prestasi belajar. Penelitian ini bersifat inkuiri melalui refleksi diri, sedangkan menurut Sanford (Dimyati, 2013) penelitian tindakan kelas adalah suatu kegiatan siklus bersifat menyeluruh yang terdiri atas analisis, pelaksanaan, penemuan fakta tambahan, dan evaluasi.

Berdasarkan pendapat ahli dapat di simpulkan bahwa penelitian tindakan kelas adalah adalah pengkajian masalah pembelajaran di dalam kelas melalui refleksi diri untuk memecahkan masalah dengan cara melakukan berbagai tindakan terencana dalam situasi nyata yang diberikan oleh guru kepada anak dan bertujuan untuk memperbaiki mutu praktik pembelajaran di kelas melalui penelitian yang reflektif, partisipatif, kolaboratif, dan spiral serta bersifat menyeluruh terdiri atas analisis, pelaksanaan, pertemuan fakta tambahan dan evaluasi.

Penelitian tindakan yang ideal dilakukan secara berpasangan (penelitian kolaborasi) antara pihak yang melakukan tindakan dan pihak yang mengamati jalannya tindakan (Dimyati, 2013, hal 129). Pihak yang melakukan tindakan adalah guru sedangkan yang melakukan pengamatan adalah peneliti. Berdasarkan pendapat tersebut penelitian tindakan kelas yang akan dilaksanakan oleh peneliti berupa kolaborasi antara peneliti dan guru, dimana guru melakukan 
tindakan dan peneliti mengamati jalannya tindakan.

\section{Variabel Penelitian}

Variabel dalam penelitian ini adalah karakter tanggung jawab melalui metode proyek pada anak kelompok B taman kanak-kanak.

\section{Lokasi Penelitian}

Penelitian ini dilaksanakan di TK Marfu'ah kelompok B yang beralamat di Jalan. Sukamaju, Kecamatan. Sukarami, Kota Palembang.

\section{Waktu Penelitian}

Pelaksanaan penelitian dilakukan pada semester ganjil tahun ajaran $2017 / 2018$

\section{Subjek Penelitian}

Anak Kelompok B di TK Marfu'ah Palembang pada semester Ganjil Tahun Ajaran 2017/2018 dengan jumlah 16 orang siswa, yang terdiri dari 8 anak lakilaki dan 8 anak perempuan

\section{Rancangan Penelitian}

Penelitian ini dirancang dengan melakukan tahapan-tahapan yang akan di gambarkan seperti dibawah ini. Ada beberapa ahli yang mengemukakan model penelitian tindakan dengan bagan yang berbeda, namun secara garis besar terdapat empat tahapan yang lazim dilalui, yaitu (1) perencanaan (2) pelaksanaan, (3)pengamatan, (4) refleksi.

Kemudian peneliti menyiapkan perangkat pembelajaran, yang terdiri dari : (a) Menyiapkan Rencana Kegiatan Harian (RKH), (b) Menyiapkan alat dan bahan (seperti kertas dan lem), (c) Mengkaji materi sesuai dengan tema yang akan disampaikan, (d) Menyiapkan lembar observasi untuk anak, (d) Menyiapkan lembar observasi untuk guru yang berbentuk chek list.

\section{Teknik Pengumpulan Data}

Teknik pengumpulan data pada penelitian ini yaitu berupa tes perbuatan dan observasi

\section{Observasi}

Tujuan utama dari observasi, yaitu: mengumpulkan data dan untuk mengukur perilaku kelas (Wina Sanjaya, 2013:86). Alat yang digunakan dalam melakukan observasi disebut pedoman observasi. Metode observasi digunakan oleh peneliti untuk mengumpulkan data penelitian yang berupa perilaku, atau perbuatan yang sedang dilakukan oleh subjek penelitian. Observer mempersiapkan pedoman pengamatan secara detail sekaligus menyediakan daftar check list yang biasa digunakan sebagai pedoman pengamatan. Lembar observasi digunakan untuk mengetahui kemampuan anak tentang karakter tanggung jawab. Observasi tersebut dilakukan oleh peneliti untuk mengamati guru serta aktivitas anak tanpa mengganggu kegiatan anak.

\section{Tes}

Tes adalah alat atau prosedur yang dipopulerkan dalam rangka pengukuran dan penilaian yang dapat berupa pertanyaan, perntah dan petunjuk yang ditujukan kepada peserta didik untuk mendapatkan respons sesuai dengan petunjuk untuk mengukur ingkat kemampuan anak (Daryanto, 2016:71). Tes yang akan digunakan oleh peneliti ialah tes perbuatan berikut ini kisi-kisi karakter tanggung jawab anak melalui metode proyek. Tes perbuatan dilakukan dengan cara menyuruh peserta didik untuk melakukan suatu pekerjaan.

\section{Definisi Konseptual}

Definisi Karakter Tanggung Jawab

Karakter tanggung jawab adalah suatu kewajiban untuk melakukan atau menyelesaikan tugas yang harus di penuhi, memiliki konsekuensi hukuman terhadap kegagalan, dan mengerjakan tugas sebaik mungkin, tidak menyalahkan 
orang lain bila terjadi kesalahan dalam melakukan tugas yang diemban serta terfokus pada tujuan untuk mendapatkan hasil yang maksimal dengan menekankan sikap positif seperti memberikan bantuan kepada orang yang membutuhkan.

\section{Definisi Metode Proyek}

Metode proyek adalah cara pemberian pengalaman belajar dengan menghadapkan anak dalam persoalan sehari-hari tentang topik tertentu yang dapat dipecahkan secara berkelompok maupun individu untuk mencapai tujuan dimana bahan yang digunakan diorganisasikan sedemikian rupa sehingga lebih bermakna.

Definisi operasional karakter tanggung jawab adalah sebagai berikut : 1) Mengerjakan tugas, 2) Menyelesaikan tugas, 3) Konsekuensi, 4) Hasil maksimal.

\section{Metode Proyek}

Selanjutnya metode proyek yang akan menjadi indikator adalah: proyek ulang tahun, proyek penghijauan lingkungan, proyek replika kendaraan, dan proyek hewan air.

\section{Metode Analisis Data}

Data hasil observasi yang diperoleh akan dihitung perindikator, kemudian menghitung persentasenya. Pada analisis data dimasukkan ke dalam kualitatif perkembangan anak melalui metode proyek. Untuk memperoleh persentase tingkat keberhasilan anak terhadap pembelajaran yang telah diajarkan digunakan rumus untuk mengetahui keberhasilan sebagai berikut.

$$
\text { Persentase }=\frac{\text { skor yang diperoleh }}{\text { skor maksimal }} \times 100 \%
$$

Sunarti \& Rahmawati, (2014:50)

Menghitung nilai rata-rata setiap pertemuan

$$
M=\frac{\sum x}{N}
$$

Keterangan :

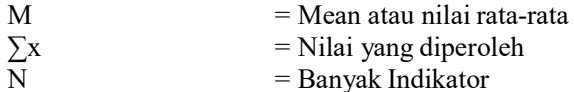

\section{HASIL PENELITIAN DAN PEMBAHASAN \\ Hasil Penelitian}

Pada bagian ini diuraikan hasil penelitian yang dilaksanakan di TK Marfu'ah Palembang. Untuk meningkatkan karakter tanggung jawab pada anak. Peneliti memilih dengan menggunakan metode proyek. Pelaksanaan peneliti ini dilaksanakan dalam empat siklus yaitu siklus I, siklus II, siklus III, dan siklus IV serta pembahasannya sebagai berikut:

Siklus 1

Berdasarkan hasil observasi yang dilakukan pada siklus I sebagian anak sudah dapat bertanggung jawab tanpa peringatan dari guru dan teman lagi, walaupun masih ada juga yang masih diperingatkan guru dan teman. Data hasil observasi akan ditunjukkan pada tabel 1 . berikut ini:

Tabel 1. Data Hasil Observasi Karakter Tanggung Jawab Melalui Metode Proyek pada Siklus I

\begin{tabular}{|l|c|c|l|}
\hline Interval & $\begin{array}{c}\text { Jumlah } \\
\text { Anak }\end{array}$ & $\begin{array}{c}\text { Persentase } \\
(\%)\end{array}$ & Kriteria \\
\hline $25-43$ & 6 & 38 & $\mathrm{BB}$ \\
\hline $44-62$ & 5 & 31 & $\mathrm{MB}$ \\
\hline $63-81$ & 4 & 25 & $\mathrm{BSH}$ \\
\hline $82-100$ & 1 & 6 & $\mathrm{BSB}$ \\
\hline
\end{tabular}

- BB : Belum Berkembang

- MB : Mulai Berkembang

- BSH : Berkembang Sesuai Harapan

- BSB : Berkembang Sangat Baik

Hal ini dapat dilihat dari hasil observasi yang menunjukkan bahwa ada 1 anak atau $(6 \%)$ anak yang mendapat nilai pada rentang 82-100 yaitu Eza dikategorikan berkembang sangat baik (BSB) karena anak mengerjakan tugas, menyelesaikan tugas, menerima 
konsekuensi dan mendapatkan hasil yang maksimal. Ada 5 anak atau (31\%) anak yang mendapat nilai pada rentang 63-81 yaitu Amir, Arradhalia, Acello, dan Adam dikategorikan berkembang sesuai harapan (BSH) karena anak mengerjakan tugas, menyelesaikan tugas, dan menerima konsekuensi. Anak yang mendapat nilai pada rentang 44-62 ada 4 anak atau (25\%) anak yaitu Mutia, Yessi, Dahlia, Yogi, dan Aqeel dikategorikan mulai berkembang (MB) karena anak-anak tersebut mengerjakan tugas, dan menyelesaikan tugas dengan peringatan guru. Anak yang mendapat nilai pada rentang 25-43 ada 6 anak atau (38\%) yaitu Cikho, Wahyu, Warna, Yogi, Putri dan Zhezhe dikategorikan belum berkembang, karena anak hanya mengerjakan tugas belum menyelesaikan tugas dan belum bisa menerima konsekuensi, serta belum mendapatkan hasil yang maksimal.

Jadi ada 6 anak dikategorikan belum berkembang (BB) dengan perentase $38 \%, 5$ anak yang dikategorikan mulai berkembang (MB) dengan hasil persentase 25\%, 4 anak dikategorikan berkembang sesuai harapan $(\mathrm{BSH})$ dengan hasil persentase $31 \%$, dan 1 anak dikategorikan berkembang sangat baik (BSB) dengan hasil persentase $6 \%$. Untuk itu penulis dapat melihat kekurangan yang ada pada siklus I dan menjadi bahan rencana lanjutan pada siklus II untuk meningkatkan karakter tanggung jawab melalui metode proyek.

\section{Siklus II}

Selama kegiatan pembelajaran berlangsung dilakukan pengamatan dengan menggunakan lembar observasi. Hampir sebagian anak berada pada kriteria berkembang sangat baik (BSB) karena sudah menyelesaikan tugas dan menerima konsekuensi. Data hasil observasi akan ditunjukkan pada tabel 2 . berikut ini:
Tabel 2. Data Hasil Observasi Karakter Tanggung Jawab Melalui Metode Proyek Pada Siklus II

\begin{tabular}{|c|c|c|c|}
\hline Interval & $\begin{array}{c}\text { Jumlah } \\
\text { Anak }\end{array}$ & $\begin{array}{c}\text { Persentase } \\
(\%)\end{array}$ & Kriteria \\
\hline $\mathbf{2 5 - 4 3}$ & 3 & $19 \%$ & BB \\
\hline $\mathbf{4 4 - 6 2}$ & 4 & $25 \%$ & MB \\
\hline $\mathbf{6 3 - 8 1}$ & 7 & $44 \%$ & BSH \\
\hline $\mathbf{8 2 - 1 0 0}$ & 2 & $12 \%$ & BSB \\
\hline
\end{tabular}

Keterangan :

- BB : Belum Berkembang

- MB : Mulai Berkembang

- BSH: Berkembang Sesuai Harapan

- BSB : Berkembang SangatBaik

Hasil observasi menunjukkan bahwa ada 3 anak (19\%) yang mendapat nilai rentang 25-43 yaitu Wahyu, Warna, dan Zhezhe di kategorikan belum berkembang karena anak mengerjakan tugas, namun belum menyelesaikan tugas, dan belum menerima konsekuensi serta mendapatkan hasil yang maksimal ketika diberikan tugas. Ada 4 anak (25\%) yang mendapat nilai pada rentang 44-62 yaitu Cikho, Yogi, Putri, dan Yessi dikategorikan mulai berkembang (MB) karena anak tersebut mulai mengerjakan tugas dan menyelesaikan tugas, namun belum menerima konsekuensi dan belum mendapatkan hasil yang maksimal setelah diberikan tugas dengan peringatan guru. Anak yang mendapat nilai pada rentang 63-81 ada 7 anak (44\%) yaitu Acello, Aradhalia, Aqeel, Amir, Mutia, Dahlia, dan Dani dikategorikan berkembang sesuai harapan (BSH) karena anak mengerjakan tugas, menyelesaikan tugas, menerima konsekuensi. Akan tetapi belum mendapatkan hasil yang maksimal setelah diberikan contoh oleh guru. Anak yang mendapat nilai pada rentang 82-100 ada 2 anak (12\%) yaitu Adam dan Eza dikategorikan berkembang sangat baik (BSB) karena anak dapat mengerjakan tugas, menyelesaikan tugas, menerima konsekuensi dan mendapatkan hasil yang maksimal setelah diberikan tugas tanpa bantuan guru. Untuk itu penulis dapat 
melihat kekurangan dan menjadi bahan rencana lanjutan pada siklus III dalam proses meningkatkan karakter tanggung jawab melalui metode proyek.

\section{Siklus III}

Berdasarkan hasil observasi yang dilakukan pada siklus III sebagian anak sudah dapat bertanggung jawab, walaupun masih ada juga yang masih diperingatkan guru dan teman saat berprilaku melakukannya. Data hasil observasi akan ditunjukkan pada tabel 3. berikut ini:

Tabel 3. Data Hasil Observasi Karakter Tanggung Jawab Anak Melalui Metode Proyek Pada Siklus III

\begin{tabular}{|l|c|l|l|}
\hline Interval & $\begin{array}{l}\text { Jumlah } \\
\text { Anak }\end{array}$ & $\begin{array}{l}\text { Persentase } \\
(\%)\end{array}$ & Kriteria \\
\hline $\mathbf{2 5 - 4 3}$ & 2 & $12 \%$ & $\mathrm{BB}$ \\
\hline $\mathbf{4 4 - 6 2}$ & 3 & $19 \%$ & $\mathrm{MB}$ \\
\hline $\mathbf{6 3 - 8 1}$ & 7 & $44 \%$ & $\mathrm{BSH}$ \\
\hline $\mathbf{8 2 - 1 0 0}$ & 4 & $25 \%$ & $\mathrm{BSB}$ \\
\hline
\end{tabular}

Hasil observasi menunjukkan bahwa ada dua anak (12\%) yang mendapat nilai rentang 25-43 yaitu Zhezhe dan Warna karena anak hanya mengerjakan tugas. Ada 3 anak (19\%) yang mendapat nilai pada rentang 44-62 yaitu Wahyu, Cikho, dan Yogi dikategorikan mulai berkembang (MB) karena anak mengerjakan tugas dan menyelesaikan tugas. Namun, belum menerima konsekuensi dan belum mendapatkan hasil yang maksimal. Anak yang mendapat nilai pada rentang 63-81 ada 7 anak (44\%) yaitu Aqeel, Amir, Aradhalia, Dahlia, Dani, Putri dan Yessi dikategorikan berkembang sesuai harapan (BSH) karena anak mengerjakan tugas, menyelesaikan tugas dan menerima konsekuensi. Anak yang mendapat nilai pada rentang 82-100 ada 4 anak (25\%) yaitu Adam, Acello, Putri dan Eza dikategorikan berkembang sangat baik (BSB) karena anak mengerjakan tugas, menyelesaikan tugas, menerima konsekuensi dan mendapatkan hasil yang maksimal dengan sendirinya.

\section{Siklus IV}

Kegiatan pembelajaran pada pertemuan 2 ini sebagian anak berada pada kriteria berkembang sangat baik (BSB) karena mengerjakan tugas, menyelesaikan tugas, menerima konsekuensi dan mendapatkan hasil yang maksimal. Data hasil observasi akan ditunjukkan pada tabel 4 . berikut ini:

Tabel 4. Data Hasil Observasi Karakter Tangggung Jawab Melalui Metode Proyek Pada Siklus IV

\begin{tabular}{|l|c|l|l|}
\hline Interval & $\begin{array}{l}\text { Jumlah } \\
\text { Anak }\end{array}$ & $\begin{array}{l}\text { Persentase } \\
(\%)\end{array}$ & Kriteria \\
\hline $\mathbf{2 5 - 4 3}$ & 1 & 6 & $\mathrm{BB}$ \\
\hline $\mathbf{4 4 - 6 2}$ & 2 & 12 & $\mathrm{MB}$ \\
\hline $\mathbf{6 3 - 8 1}$ & 7 & 44 & $\mathrm{BSH}$ \\
\hline $\mathbf{8 2 - 1 0 0}$ & 6 & 38 & $\mathrm{BSB}$ \\
\hline
\end{tabular}

Keterangan :

- BB : Belum Berkembang

- MB : Mulai Berkembang

- BSH: Berkembang Sesuai Harapan

- BSB : Berkembang SangatBaik

Hasil observasi menunjukkan bahwa ada satu anak (6\%) yang mendapat nilai rentang 25-43 yaitu Zhezhe. Dua anak $(12 \%)$ yang mendapat nilai pada rentang 44-62 yaitu Wahyu dan Warna, karena mengerjakan tugas dan menyelesaikan tugas. Namun, belum menerima konsekuensi dan belum mendapatkan hasil yang maksimal. Anak yang mendapat nilai pada rentang 63-81 ada 7 anak (44\%) yaitu Aqeel, Cikho, Dahlia, Yogi, Putri, Yessi, dan Dani dikategorikan berkembang sesuai harapan (BSH) karena anak mendapatkan mengerjakan tugas, menyelesaikan tugas, menerima konsekuensi. Anak yang mendapat nilai pada rentang 82-100 ada 6 anak (38\%) yaitu Adam, Acello, Aradhalia, Eza, Mutia, Amir dikategorikan berkembang sangat baik (BSB) karena anak 
mengerjakan tugas, menyelesaikan tugas, menerima konsekuensi dan mendapatkan hasil yang maksimal.

\section{Rekapitulasi Hasil Observasi}

Rekapitulasi hasil pengamatan terhadap karakter tanggung jawab anak melalui metode proyek yang telah dilakukan pada siklus I, II, III, dan IV, terlihat bahwa adanya peningkatan dari data siklus I dan telah mencapai ketuntasan.Untuk lebih jelas dapat dilihat pada diagram dibawah ini:

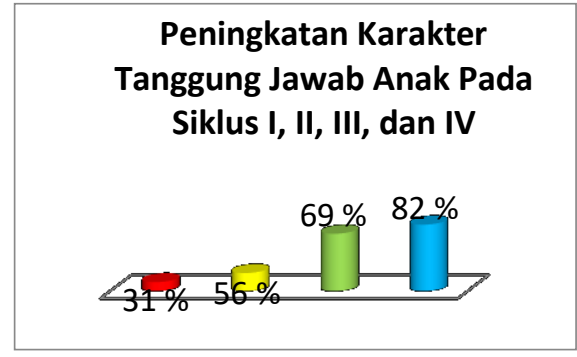

Diagram 1. Diagram Batang Hasil Rekapitulasi Observasi Terhadap Karakter Tanggung Jawab Melalui Metode Proyek Anak Pada Siklus I, II, III, dan IV.

Diagram 4.3 terlihat adanya peningkatan pada hasil dari Siklus IV lebih tinggi $82 \%$ dari Siklus III 69\%, dan hasil Siklus III lebih tinggi $69 \%$ dari Siklus II 56\%, dan hasil Siklus II lebih tinggi 56\% dari Siklus $31 \%$.

\section{Pembahasan}

Berdasarkan hasil persentase pada hasil penelitian terdapat perubahan pada siklus I, ke siklus II kemudian meningat lagi pada siklus III dan meningkat lebih tinggi pada siklus IV, karakter tanggung melalui metode proyek anak menjadi lebih meningkat dari siklus ke siklus. Artinya melalui metode proyek dapat meningkatkan karakter tanggung jawab anak di kelompok B TK Marfu'ah Palembang yang dilakukan peneliti selama penelitian.

Pembiasaan yang diterapkan guru sangat penting dalam proses belajar dan mengajar yang ada didalam kelas, karena sebagai dasar keterampilan dalam mengelola kelas dan menciptakan suasana belajar yang menyenangkan bagi anak menggunakan hal yang baru untuk anak salah satunya dengan metode proyek. Kegiatan proyek sedemikian rupa dan disesuaikan dengan tujuan pembelajaran agar terlaksana belajar melalui pembiasaan sehingga anak bisa mengikuti proses pembelajaran tanpa beban. Metode ini didukung oleh Waluya (2013) Kegiatan proyek untuk anak usia dini sangat penting untuk dimunculkan sedini mungkin sebagai pondasi yang paling dasar dalam proses pertumbuhan dan perkembangan seluruh potensi yang dimilikinya, demikian juga dalam proses sosialisasi diri dalam lingkungan hidupnya.

Kegiatan anak usia dini akan lebih menyenangkan dan menarik jika di setiap kegiatan menggunakan metode yang menarik salah satunya menggunakan metode proyek anak akan di latih perilaku dalam sehari-hari dan dapat memiliki karakter tanggung jawab. Hal ini berkaitan dengan pendapat Yaumi (2013) berpendapat bahwa tujuan pembelajaran metode proyek tidak hanya untuk melatih kerjasamaa namun lebih menekankan pada tanggung jawab. Menurut Wina Sanjaya (2014) metode proyek dapat meningkatkan komunikasi yang baik antra kelompok. Senada dengan pendapat Sriwayuni (2015) dengan metode proyek dapat meningkatkan karakter tanggung jawab. Metode proyek merupakan strategi yang efektif untuk membentuk perilaku tertentu pada anak- anak, termasuk karakter tanggung jawab.

Pada peningkatan karakter tanggung jawab melalui metode proyek peneliti dan guru berkolaborasi dalam proses pembelajaran. Dalam satu siklus terdapat 3 pertemuan, setiap pertemuan menggunakan indikator yang berbeda seperti mengerjakan tugas, menyelesaikan tugas, menerima konsekuensi dan mendapatkan hasil yang maksimal. Peneliti mengumpulkan data 
tentang karakter tanggung jawab dengan observasi dan melihat hasil penilaian pra penilitian pada pra siklus menggunakan observasi. Setelah melihat observasi yang diperoleh lalu dihitung kemudian didapat hasil penilaian anak pada pra siklus diperoleh kriteria belum berkembang ada 8 anak atau $50 \%$, pada kriteria mulai berkembang ada 4 orang anak atau 19\%, lalu kriteria berkembang sesuai harapan ada 3 anak atau 19\% dan anak berhasil mencapai kriteria berkembang sangatbaik ada 1 anak atau $6 \%$. Jika dilihat pada hasil ini menunjukan lebih dari setengah anak masih dalam kriteria belum berkembang dan mulai berkembang ada 12 anak atau sebesar 75\%. Maka peneliti akan melanjutkan penelitian ke siklus.

Pada siklus I dilaksanakan pada hari Rabu, tangggal 13 september 2017 dengan tema diriku subtema identitasku. Indikator yang digunakan yaitu mengerjakan tugas, menyelesaikan tugas, menerima konsekuensi dan mendapatkan hasil yang maksimal. Hasil observasi menunjukkan bahwa ada 1 anak $(6 \%)$ yang mendapat nilai $82-100$ kataegori berkembang sangat baik (BSB), ada 4 anak (25\%) yang mendapat nilai pada rentang 63-81 dikategorikan berkembang sesuai harapan (BSH). Ada 5 anak (31\%) dikategorikan mulai berkembang (MB). Anak yang mendapat nilai pada rentang 25-43 ada 6 anak (38\%) dikategorikan belum berkembang (BB)

Pada siklus II dilakukan pada hari Rabu tanggal 20 September 2017 dengan tema diriku sub tema panca indra. Indikator yang digunakan yaitu mengerjakan tugas, menyelesaikan tugas, menerima konsekuensi dan mendapatkan hasil yang maksimal. Hasil observasi menunjukkan bahwa ada 2 anak (12\%) yang mendapat nilai pada rentang 82-100 dikategorikan berkembang sangat baik (BSB). Ada 7 anak (44\%) yang mendapat nilai pada rentang 63-81 dikategorikan berkembang sesuai harapan (BSH). Anak yang mendapat nilai pada rentang 44-62 ada 4 anak (25\%) dikategorikan mulai berkembang (MB). Anak yang mendapat nilai pada rentang 25-49 ada 3 anak (19\%) dikategorikan belum berkembang (BB).

Pelaksanaan siklus III dilakukan pada hari Sabtu, tanggal 30 September 2017 dengan tema diriku subtema anggota tubuh. Indikator yang digunakan yaitu mengerjakan tugas, menyelesaikan tugas, menerima konsekuensi dan mendapatkan hasil yang maksimal. Hasil observasi menunjukkan bahwa ada 2 anak (6\%) dikategorikan belum berkembang (BB). Ada 4 anak (19\%) Dikategorikan mulai berkembang (MB). Anak yang mendapat nilai pada rentang 63- 81 ada 7 anak (44\%) dikategorikan berkembang sesuai harapan (BSH). Anak yang mendapat nilai pada rentang $82-100$ ada 4 anak (25\%) dikategorikan berkembang sangat baik (BSB).

Pada siklus IV dilakukan pada hari Kamis, tanggal 05 Oktober 2017 dengan tema diriku dan subtema bagian kesukaanku. Indikator yang digunakan yaitu mengerjakan tugas, menyelesaikan tugas, menerima konsekuensi dan mendapatkan hasil yang maksimal. Hasil observasi pada pertemuan ini menunjukkan bahwa ada 1 anak $(6 \%)$ anak yang dikategorikan belum berkembang (BB) dan ada 2 anak (6\%) yaitu Wahyu dan Warna dikategorikan mulai berkembang (MB). Ada 7 anak (50\%) yaitu Cikho, Aqeel, Dahlia, Yogi, Putri, dan Yessi dikategorikan berkembang sesuai harapan (BSH). Ada 6 anak (38\%) Amir, Adam, Acello, Aradhalia, Eza, dan Mutia dikategorikan berkembang sangat baik (BSB) .

Dari data di atas terlihat adanya peningkatan pada hasil dari Siklus IV lebih tinggi sebanyak $82 \%$ dari Siklus III sebanyak $69 \%$, dan hasil Siklus III lebih tinggi sebanyak $69 \%$ dari Siklus II sebanyak 56\%, dan hasil Siklus II lebih tinggi 56\% dari Siklus I sebanyak 31\%.

Penelitian ini didukung oleh penelitian yang dilakukan dalam 
Kegiatan Pengembangan Karakter Tanggung Jawab di TK Nurhidayah (2014) metode proyek dapat dikatakan dapat meningkatkan karakter tanggung jawab. Karena metode proyek salah satu cara untuk meningkatkan tanggung jawab.

\section{KESIMPULAN}

Berdasarkan hasil penelitian dan pembahasan yang telah diuraikan, dapat di katakan bahwa terdapat peningkatan metode proyek terhadap karakter tanggung jawab anak pada kelompok B TK Marfu'ah Palembang. Hal ini dibuktikan dengan hasil pengamatan data yang diperoleh peningkatan karakter tanggung jawab anak, dengan melalui metode proyek.

Dari hasil pengamatan di atas terlihat adanya peningkatan pada hasil dari Siklus IV lebih tinggi sebanyak $82 \%$ dari Siklus III sebanyak 69\%, dan hasil Siklus III lebih tinggi sebanyak 69\% dari Siklus II sebanyak 56\%, dan hasil Siklus II lebih tinggi 56\% dari Siklus I sebanyak $31 \%$. Hal ini terbukti semua indikator muncul dari hasil pengamatan pada akhir siklus IV semua anak mengerjakan tugas, anak menyelesaikan tugas, anak menerima konsekuensi dan anak mendapatkan hasil yang maksimal. Maka dapat disimpulkan adanya peningkatan karakter tanggung jawab anak melalui metode proyek pada anak kelompok B TK Marfu'ah Palembang.

\section{DAFTAR PUSTAKA}

Dimyati, J. (2013). Metodologi Penelitian Pendidikan \& Aplikasinya. Jakarta: Kencana Prenada Media Grup.

Khayrunnisa. (2014). Pengaruh Penggunaan Metode Proyek terhadap Perkembangan Kreativitas Anak Usia 5-6 tahun di TK Aisyiyah Binjai Tahun Ajaran 2013/2014. Skripsi. Medan: Universitas Medan.

Latif,dkk. (2013). Orientasi Pendidikan Anak Usia Dini. Jakarta: Kencana Prenada Media Group.
Najib, M. dkk. (2016). Manajemen Strategik Pendidikan Karakter Bagi Anak Usia Dini. Yogyakarta: Gava Media.

Siti Arbiah, dkk. (2014). Penerapan Metode Proyek Untuk Meningkatkan Sikap Tanggung Jawab Pada Anak Kelompok A TKIT Nur Hidayah Surakarta Tahun Ajaran 2013/2014. Jurnal. Pemalang: Universitas Muhammadiyah Surakarta. jurnal.fkip.uns.ac.id/index.php/paud/ article/.../4055. Diakses pada tanggal 28 Juli 2017.

Wina, S. (2013). Penelitian Tindakan Kelas. Jakarta: PT. Kencana Prenamedia Group

Yaumi, M. (2014). Pendidikan Karakter: Landasan, Pilar, Implementasi. Jakarta: Prenamedia Group 